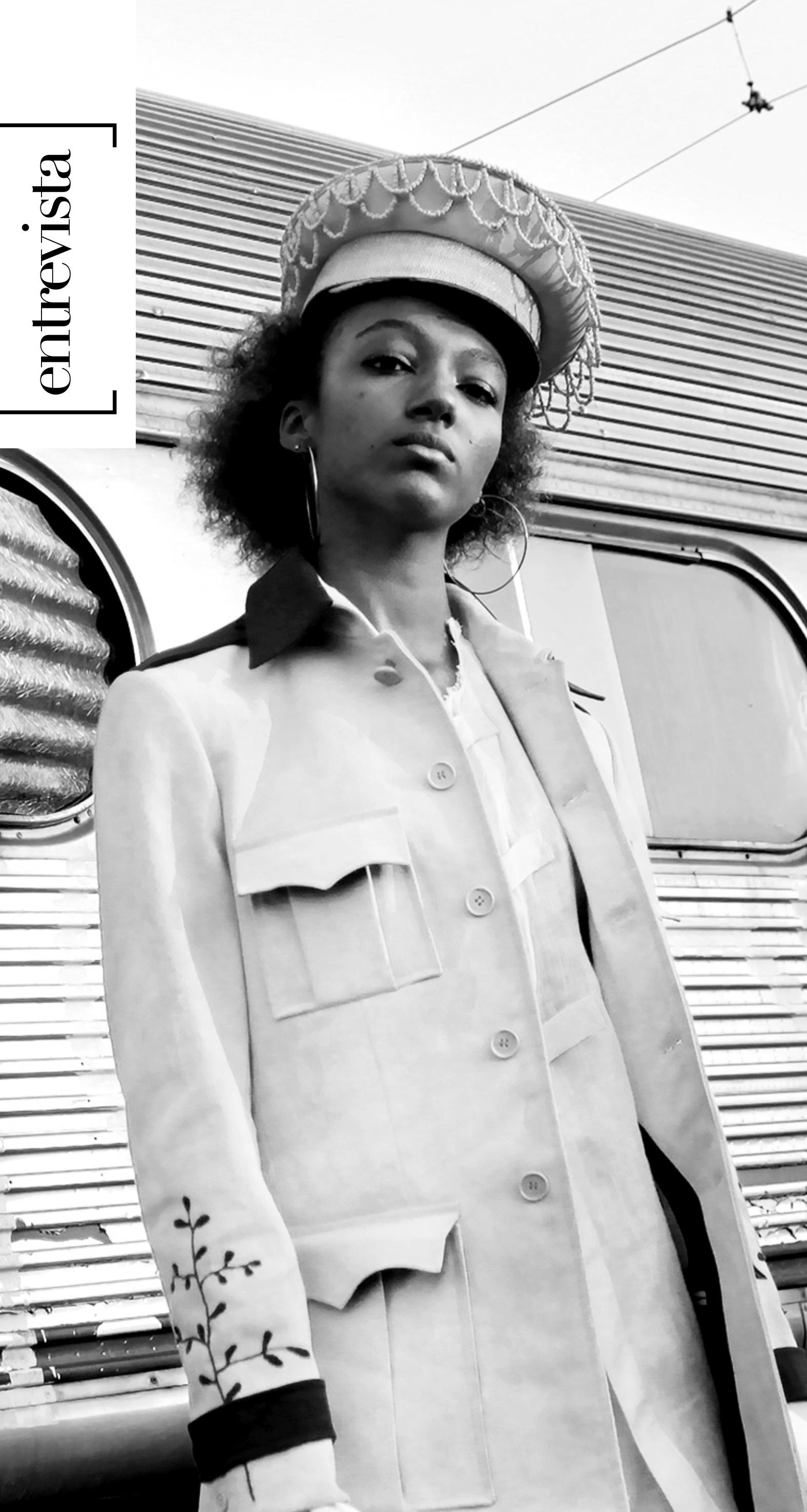




\author{
[ROGÉRIO ORTIZ] \\ Doutorando em Comunicação e Semiótica pela PUC-SP. Dirige a Sofia \\ Filmes Produtora em Audiovisual. \\ E-mail: contato@rogerioortiz.com.br \\ [KATHIA CASTILHO] \\ Doutora em Comunicação e Semiótica pela PUC-SP. Dirige a Estação \\ das Letras e Cores Editora. \\ E-mail: katcast@uol.com.br
}

\title{
Processo criativo do "Moda para Todos". Uma experiência criativa e colaborativa com o designer João Pimenta
}


Para fazer valer a expressão "corpos na moda", é necessário possibilitar a emancipação dos padrões que se repetem. Há que se ajudar novas corporeidades, a saber: ouvir seus ritmos e compreender suas possiveis e necessárias inserções no mundo promovido pela moda e, ao espectador, ajudar a reconhecer as singularidades e padrões plurais de belezas.

0 corpo compõe e troca midiaticamente com o ambiente, transforma-se, dá-se a ver e propõe um fazer sensorial, estético e estésico em suas narrativas. É nesta interação e troca que, durante a organização e, mais especialmente, para a abertura do $13^{\circ}$ Colóquio de Moda, realizado na cidade de Bauru (SP) entre os dias 11 e 15 de outubro de 2017, que o desfile "Moda para Todos" foi proposto e encontrou no designer João Pimenta a parceria de diálogo que engrena novas construções perceptivas. Este projeto inovador envolveu os cidadãos bauruenses e os alunos da Faac/Unesp, bem como a cidade e um de seus ícones, a Estação Ferroviária de Bauru, antiga Noroeste do Brasil. Contou também com o apoio da Prefeitura Municipal de Bauru e das Secretarias de Cultura, de Desenvolvimento Econômico e de Educação, conforme informou a Profa. Dra. Mônica Moura, presidente local desta edição do evento e então membro da diretoria da Associação Brasileira de Estudos e Pesquisas em Moda (Abepem).

0 momento foi pleno de significados, de oportunidades de refletir a criação de moda, a ética, de reconhecer padrões de beleza e o fazer da moda.

Foi buscando as possiveis conexões entre alunos, cidadãos e profissionais da moda em sua multiplicidade de tarefas que, de fato, entendemos, por meio da vivência e dos registros fotográficos, outras maneiras de diferentes corpos existirem e se manifestarem como "corpo na moda". 0 que se buscava naquela antiga Estação de Trem em Bauru era fazer da vulnerabilidade (corpos instáveis, novas propostas estéticas) uma potência de vida. Toda a produção envolvida convidou os inscritos, que desejavam desfilar as criações de João Pimenta, para trilhar um novo caminho de composição, fora da "customização" dos padrões já estabelecidos midiaticamente, propondo que ali existisse uma nova possibilidade de legitimação de corpos reais constituindo e legitimando imagens de moda.

A moda esteve ali mediada pelo design, pela passarela, pela fotografia e por falas empáticas de inclusão e pelo desejo coletivo de constituir uma realidade de "Moda para Todos". Cada um dos que estiveram ali participaram efetivamente da possibilidade do co-criar, do incluir estéticas e do fazer parte. A reflexão que emerge é, de fato, sobre o que a moda coloca em evidência. 0 foco mudou da necessidade de excelência homogeneizante no desfile e na fotografia para um processo de criação no qual cada um tem a importância de ser e ter um corpo como expressão de identidade na moda validado e percebido em sua singularidade e potência. 
entrevista ] JOÃO PIMENTA

por ROGÉRIO ORTIZ | KATHIA CASTILHO

Alguns dos inscritos e suas respectivas propostas seguem abaixo. As suas redações, originais' ${ }^{1}$ mencionam a razão e o desejo do porquê estar e participar do desfile "Moda para Todos" com criações de João Pimenta.

Figura1: Maria Inês Ribeiro Bertoni, 63 anos. "Porque quero sair da minha zona de conforto e ter esse desafio do novo, quero me divertir, aprender e conhecer novas pessoas, me soltar, sentir bonita."

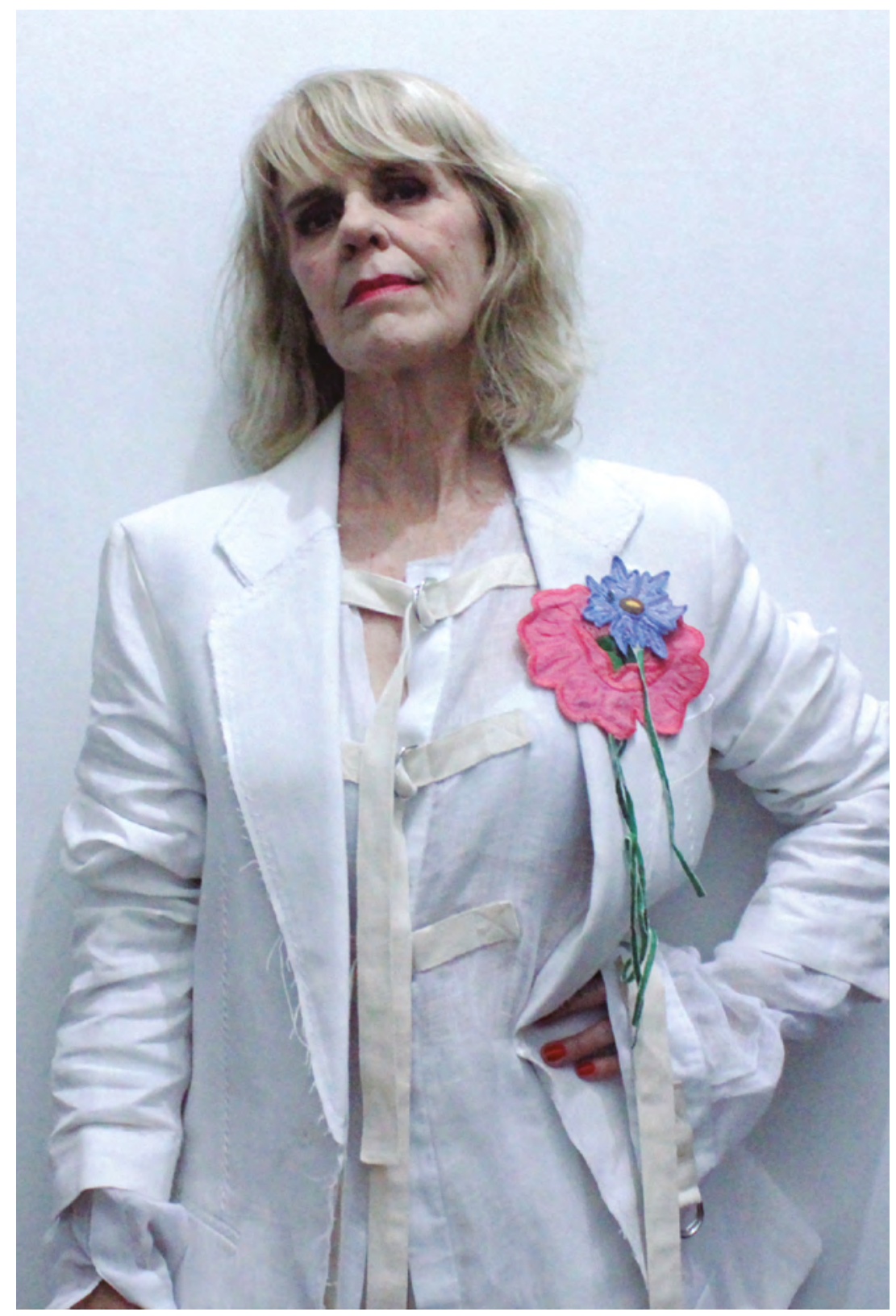

Fonte: fotografia de Rogério Ortiz (2017). 
entrevista ] JOÃO PIMENTA

por ROGÉRIO ORTIZ | KATHIA CASTILHO

Figura 2: Rafael Faria Abrão, 25 anos - altura: 1,46cm; calçado: 34; manequim: 12. "Acredito que peso e biotipo proporcionais à minha altura, eu possuo. Esta é a oportunidade de mostrar essa diferente 'proporção', que é simétrica e bela, e meu próprio estilo encontrou!"

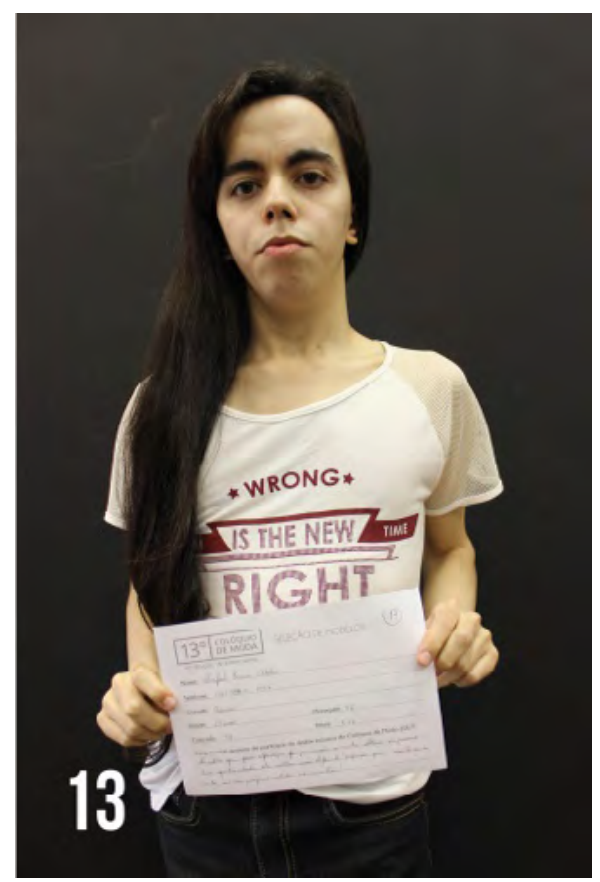

[ 325$] \quad$ Fonte: fotografia de Rogério Ortiz (2017).

Figura 3: Sudneia Costa de Oliveira, 69 anos - manequim: 46; calçado: 39; altura: 1,68. "Gostaria de participar como representante da minha comunidade, a terceira idade. Pois acredito que a presença da terceira idade nos desfiles é importante para a inclusão e bem-estar pra nós."

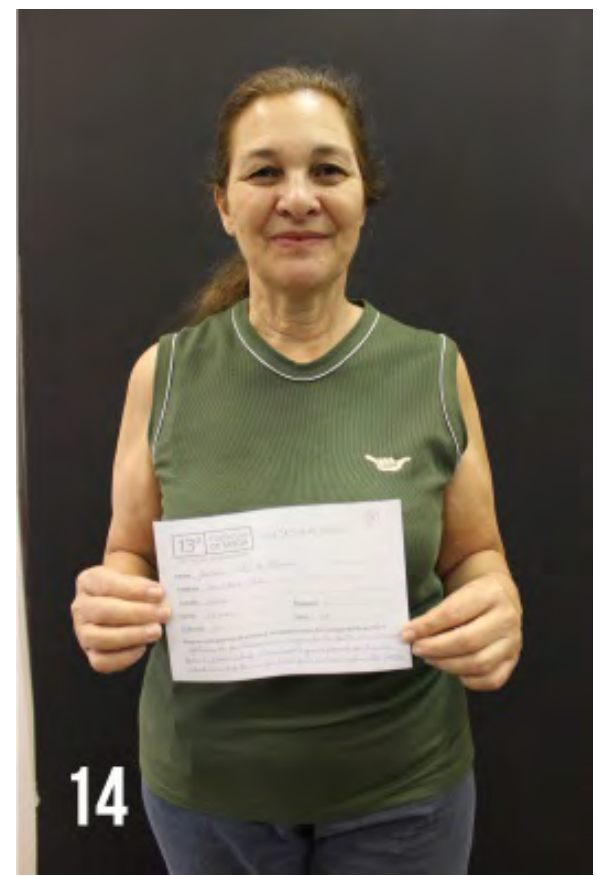

Fonte: fotografia de Rogério Ortiz (2017). 
entrevista ] JOÃO PIMENTA

por ROGÉRIO ORTIZ | KATHIA CASTILHO

Figura 4: Camila dos Santos Luiz (Garruchos Model), 28 anos - manequim: 36/38; calçado: 37; altura: 1,70. "Porque eu faço parte dessa inclusão em setores de etnia, idade, gênero e posição social. 0 desfile faz as pessoas perceberem que nossas diferenças é que nos tornam iguais".

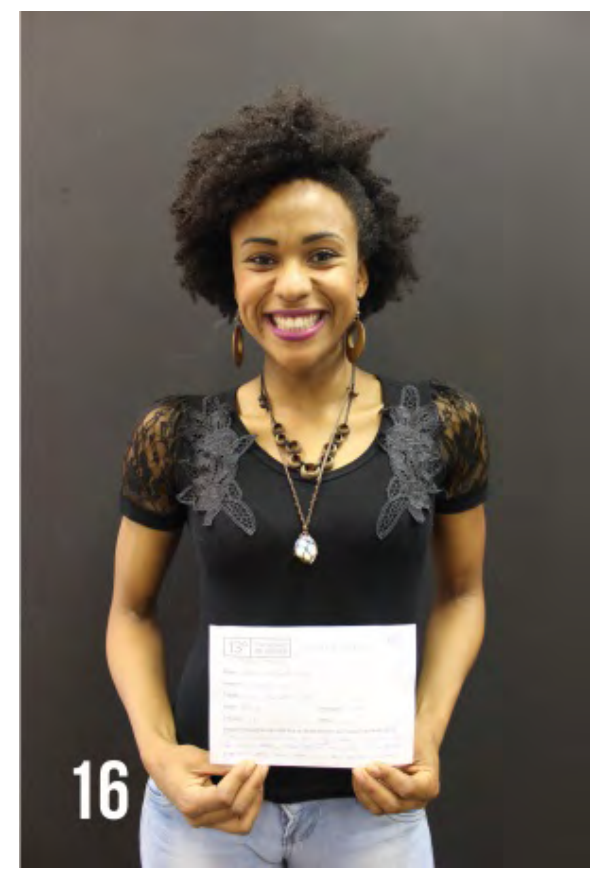

[ $\left.3^{26}\right] \quad$ Fonte: fotografia de Rogério Ortiz (2017).

Figura 5: Rebeca de Oliveira Cavenaghi, 19 anos - manequim: 36; calçado: 38; altura: 1,79. "Maior visibilidade para a causa através de uma moda mais andrógena".

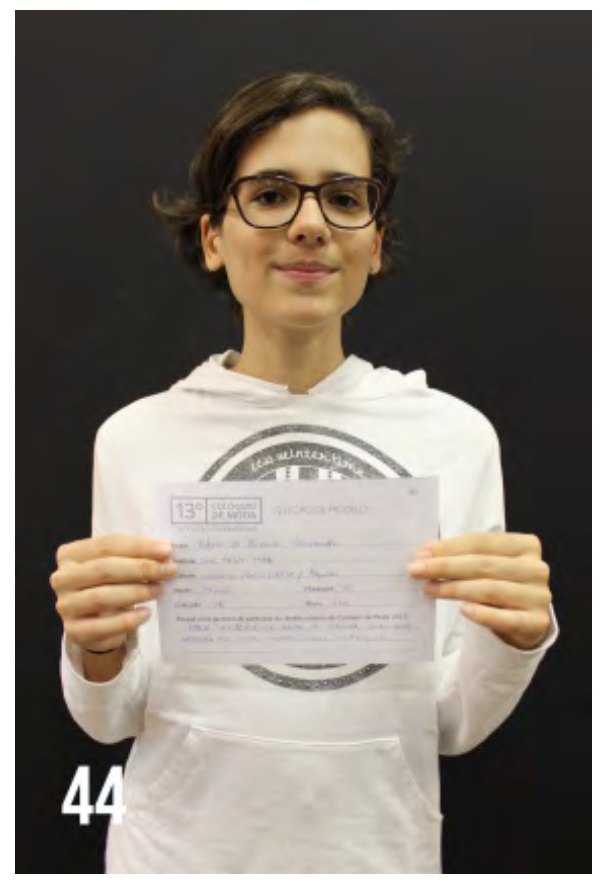

Fonte: fotografia de Rogério Ortiz (2017). 
entrevista ] JOÃO PIMENTA

por ROGÉRIO ORTIZ | KATHIA CASTILHO

Figura 6: Michel Jun Saito, 19 anos - manequim: 40; calçado: 40; altura: 1,72.

"Gosto de formas de expressão corporal (dança, tatuagem), fiquei interessado em tentar e experimentar essa oportunidade."

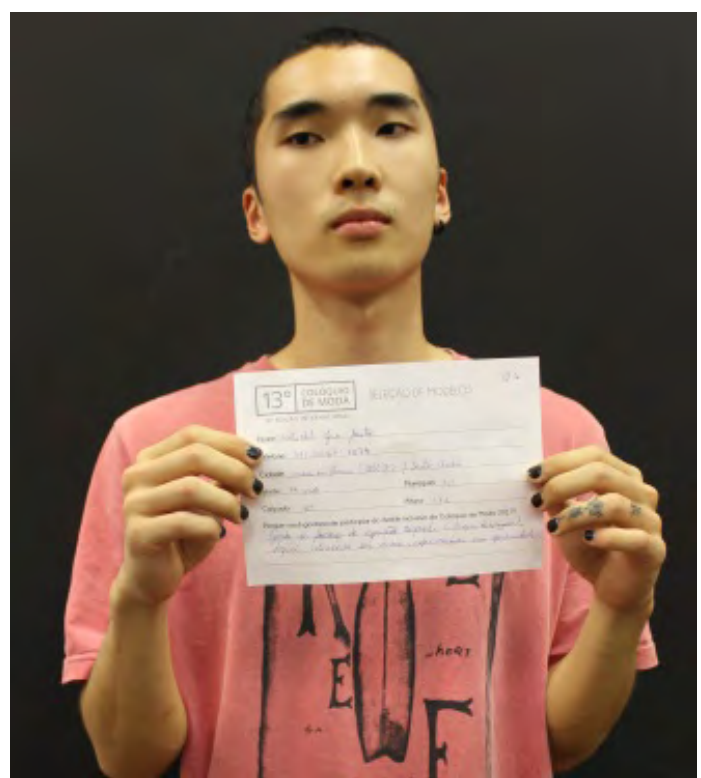

Fonte: fotografia de Rogério Ortiz (2017).

Figura7: João Ricardo Pessuth, 22 anos - manequim: 56; calçado: 43; altura:

[ 327 1,72. "Com enfoque no inofensivo, quero presenciar um desfile que seja realmente diverso. Sempre pensei em como seria a experiência de desfilar como modelo plus size masculino."

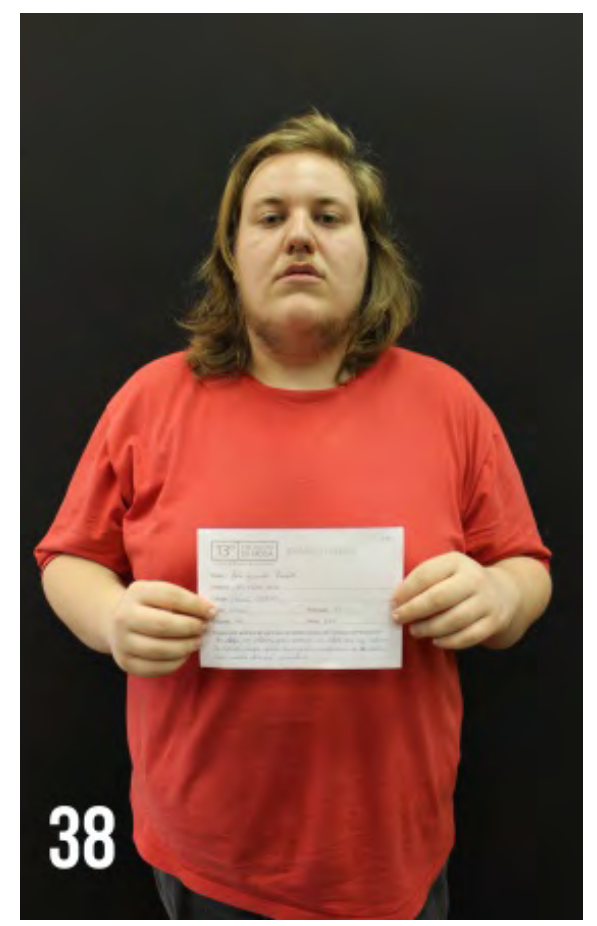

Fonte: fotografia de Rogério Ortiz (2017). 
Assim, sensibilizados com a experiência vivida e, no caso de Rogério Ortiz, documentadas pelo seu fazer fotográfico [as fotos que compõem a galeria de imagens desta edição da revista foram todas realizadas por ele em momentos que antecediam o desfile], fomos ao encontro de João Pimenta. Como um designer coloca-se frente a todo este caos, como era viver este momento de experimentação? 0 que ele pode constituir e como o fez criativamente para que o desfile acontecesse? Essas são apenas algumas das questões que nos moveram a visitá-lo em sua loja-atelier para realizar esta entrevista.

Como foi a proposta do desfile para a abertura do $13^{\circ}$ Colóquio de Moda que aconteceu na Unesp, em Bauru?

Quando pensamos "Moda para Todos" a ideia era apresentar no desfile diferentes propostas de corpos na passarela. Combinamos que receberiamos inscrições de quem desejasse desfilar. Quando eu conversei com a Mônica Moura [presidente desta edição do Colóquio] a primeira vez, para entender e discutir as coisas, nossa proposta era a de que abririamos 0 processo de seleção das pessoas que desfilariam e determinamos a prioria altura etc. e tal. Eu não faria nenhuma nova peça de roupa mas levaria meu acervo de coleções passadas, ou seja, todas as roupas já estavam confeccionadas e foram de algum modo usadas em desfiles do calendário oficial de moda. Percebemos de imediato, durante esta primeira conversa, que, se seguissemos esse caminho preestabelecido pelos processos normativos do desfile de moda, estaríamos logo de cara excluindo a própria proposta de inclusão. Selecionar significa excluir. Só isso já se configurava um grande desafio. Quem seriam as pessoas? Como seriam? Eu teria no acervo roupa capaz de vestir estes corpos? Quais os tipos de pessoas que apareceriam? Investimos na instabilidade e no acaso.

Pensamos então em nos organizar para um desfile com até 30 pessoas desfilando, mas recebemos 58 inscritos que preencheram uma ficha na qual diziam porque queriam desfilar. As razões eram distintas, mas todos acreditavam em seu potencial diferenciado de beleza. Ainda bem que foram 58, porque se tivessem aparecido 200 pessoas eu aceitaria todas após ter lido as razões e motivações, e estaria perdido!

Com as 58 inscrições na mão a Mônica me perguntou: qual vai ser 0 critério de seleção? Qual o critério de escolha?! Vamos tirar os mais altos? Ou optariamos por tamanho e medidas? Os mais novos? Os mais velhos...?! Nenhum destes parecia ser um bom critério. Nós fomos bem audaciosos em propor inclusão. Como iriamos manter um critério de inclusão tendo que excluir alguém por algum fato ou razão qualquer? Com que parâmetro? Cor de pele, altura, peso, forma de andar? Complicado, né? Para mim foi um divisor de águas este momento, por esses motivos todos de 
repensarmos a proposta e para sempre! Na minha cabeça o estereótipo do corpo da moda ainda existia fortemente e fui lidando com diferenças, com situações que só me surpreenderam.

As roupas que nós levamos também tinham uma multiplicidade na forma de vestir e de usar, no modo de compor combinações. Então, o que aconteceu foi que os inscritos estavam automaticamente selecionados $e_{\text {, }}$ para vesti-los, fui repensando, ali, no momento em que antecedia o desfile, em uma possivel adaptação, recriação em diversos aspectos. 0 principal era entender o que realmente era incluir e vestir de modo inclusivo.

Acreditamos que ações como as que aconteceram na Estação Ferroviária de Bauru, dentro de um evento acadêmico, é um bom princípio ativo para elaborarmos novos caminhos...

Eu também acredito que é papel da universidade trabalhar essa questão de novos caminhos e possibilidades. De fazer ou encaminhar processos que façam entender que lidamos com o mundo e que, na moda, temos profissões como em qualquer outra área. Você não é melhor porque trabalha com moda do que quem trabalha no banco... Tudo é parte das escolhas que você faz profissionalmente. Muitas vezes, quem trabalha na moda e até mesmo algumas faculdades querem elitizar a profissão. Querem criar estilistas sem muitas vezes saber ao certo o caminho de serviço que este profissional tem e que exerce na vida das pessoas. No mundo de hoje ninguém precisa elitizar as relações, mas sim aproximar os fazeres, fazer junto! Já foi a época na qual se entendia moda como lugar de exercício do ego, na qual a imagem do criador de moda era cada vez mais superficial e sem aprofundamento em coisa alguma. Há pouco tempo as pessoas ainda investiam neste formato, e se davam bem! Mas hoje não é mais assim. Tudo vai contra essa intenção. Novos tempos! As coisas realmente mudaram.

Durante a faculdade de cinema que eu, Rogério Ortiz, fiz, acontecia algo bem parecido com a composição e enaltecimento do papel do diretor. Eliminava-se o lado criativo de todos para potencializar um único personagem: o diretor. Destituia todo o processo de criação coletiva.

Acho que outra coisa primordial que gostaria de deixar bem claro é de onde vem o criativo. Ninguém cria sozinho. Hoje o criar é um conjunto de coisas, de pessoas, e a criação vem de todas as partes, não vem somente de um lado, não vem só do belo, do cheiro, da beleza, mas de todas as nuances sensoriais e seus contrários também. Criar essa expertise para o mundo sensivel no aluno é incrivel. Fica atento, cara! Se você perdeu um dedo, inventa uma luva de quatro dedos. Mas as pessoas têm medo de inventar a partir do que elas são, têm medo de ariscar. 
entrevista ] JOÃO PIMENTA

por ROGÉRIO ORTIZ | KATHIA CASTILHO

No seu trabalho existe um referencial muito amplo, de diversas artes e linguagens em uma mesma coleção. Você, como um profissional da moda, é também um educador, quando aponta para novos modos de ser e de fazer moda.

0 que mais me encanta é tirar as pessoas do lugar, do confortável, e promover outros olhares.

João, depois de termos vivenciado o projeto e a ação do "Moda para Todos", é interessante, agora que temos esse trabalho documentado pela memória e pelas fotos, a oportunidade de publicar aqui, na revista d0bra[s], essa nossa conversa. É um movimento artístico, político e social, uma manifestação que deve ser lembrada e exaltada, tamanha foi a potência que ali se alicerçou. É o acaso, a junção de pessoas e a vontade de fazer, é comprometimento... Daí eu pergunto: como se fez essa realidade?

É bom te ouvir falar e ter você [Rogério Ortiz] acompanhando e registrando fotograficamente todo este percurso. Nas fotos lá em Bauru, nesta conversa, em sua dissertação de mestrado... Nada combinado, mas o acaso, a aproximação, a possibilidade de continuidade da ideia ou da força da ideia que ali se manifestava e que ganha também outros sentidos e percursos, reverbera ate hoje!

Para mim, de certo modo, é tudo um incidente, meu próprio processo de criação acontece deste modo. Eu vou indo, vou seguindo sem olhar muito pra trás. Sem pensar muito no que aconteceu, parece que estou imerso em uma sequência, da vida vivida onde eu vou acontecendo ou atropelando meu próprio fazer ou processo criativo. Acontece um trabalho e já surge um novo trabalho, uma nova ideia ou possibilidade... e ai vai acontecendo e vai passando, o tempo e os trabalhos que realizo. E aqui, nesta conversa, é interessante pararmos para analisar os acontecimentos deste evento especificamente. Parece que, ao relembrar e trazer para a conversa, continuamos a criar histórias, novas possibilidades para que a gente reflita. Não que eu não achasse importante... É que, pra mim, eu já tinha concluído esse trabalho; não faz parte da rotina esse voltar e analisar. Foi tudo muito rápido no processo de elaboração da ideia do "Moda para Todos", no dia da prova de roupas com as pessoas inscritas para participar e, na sequência imediata, o desfile. Muito, muito rápido todo o processo da idealização, de criação e de execução, ou seja, de colocar todos na passarela.

Pensando nessa realidade de criação, existe uma desumanidade do próprio sistema que não dá o devido suporte ou estrutura de tempo para que o evento aconteça e se manifeste em sua potência. Acho que as pessoas envolvidas não tiveram oportunidade de saber como é complicado fazer acontecer o "show". Tem muita gente de peito aberto querendo fazer acontecer. 
Nossa, você lembra que não tínhamos quase nenhum suporte no local? 0 tempo todo imaginávamos que não ia dar certo. Até o final, surgia a mensagem de que não ia dar certo. Porque tinha tudo pra não dar certo. Parecia tudo errado e muito impossível. A Mônica Moura é uma pessoa muito incrivel. Ela se jogou naquilo tudo e fez acontecer. Algo tão absurdo, improvável e impossivel de se fazer. Foi muito deslumbrante esse acontecimento. Depois do evento eu, de fato, me perguntei: o que foi tudo aquilo para a Mônica? Para o Colóquio?! Ainda mais que nós não tivemos a oportunidade de conversar mais. Fiquei questionando o que ela teria pensado e o que as pessoas envolvidas no evento haviam pensado. [Nós, os entrevistadores, motivados por esta questão, decidimos incluir no final da entrevista o depoimento de alguns modelos que se inscreveram para 0 desfile e participaram dele].

Nós precisamos dar valor aos encontros potentes, ou melhor, fazer dos encontros potência. Foi incrivel e admirável ver você e sua equipe (Marcelo Andreotti e Bruna Fernandes) recebendo aquela avalanche de pessoas, muitos ao mesmo tempo, para a prova de roupas. E cada um com um corpo.

Você sabe que o que mais me chamou atenção, o que era o mais importante que tudo ali, naquele momento, eram as pessoas que chegavam pra se vestir. Eu queria mesmo é que a pessoa se sentisse bem com as minhas criações, com as roupas e acessórios que eu havia levado. Eu não tinha muitas opções para cada pessoa, pois eram diferentes corpos e tamanhos. Nós tínhamos um número grande de pessoas para uma quantidade limitada de roupas. $\mathrm{E}$ aí, tínhamos corpos que eram muito diferentes das roupas. E as pessoas tinham que vestir e se sentir bem. Fora isso, o mais importante é que se a pessoa não estivesse bem, não ia dar certo! Eu só pensava nisso, em fazer com que as pessoas, quando vestissem, se sentissem bem com aquilo que vestiam. Eu tinha peças bizarras, muito diferentes entre si, eram peças de pelo, de arame, eu tinha um conjunto de roupas que eu tinha consciência e entendia estarem muito longe do universo da rotina das pessoas. Então, eu fiquei o tempo todo preocupado. Não era uma roupa fácil de entendimento, o corpo era de uma pessoa que tem suas especificidades, não é como um modelo que o que você coloca funciona. $\mathrm{E}$ o que mais me interessou foi essa relação e essa busca de realizar junto das pessoas o meu processo de criação. 0 mais importante era vestir as 58 pessoas e todas sentindo-se bem, buscar o equilibrio estético, de beleza, com aquilo que somávamos ali, corpos diferenciados nos quais cada um propunha o seu e roupas que vinham de minhas propostas criativas, juntando ali várias coleções. Bem complicado isso, parecia quase impossivel, sabe? 
E esta aproximação aconteceu tão rapidamente, nas poucas horas que antecederam a apresentação. Um encontro rápido das peças que você levou pra Bauru e que vinham de várias coleções e experimentos de seu acervo. Havia nas peças escolhidas um percurso, sua história?

Sim. Mas você acredita que, ali, cada uma das peças encontrou a pessoa certa? A pessoa verdadeira que deveria vestir aquela roupa? Veja, eu tinha peças de coleções cujas referências não eram aquelas pessoas. Eu fiz e vesti outras pessoas, mas, de repente, toda a criação foi parar no ponto inicial, de experimentar e repensar quem vestiria e como cada uma das peças seria vestida. Nós fizemos, por exemplo, várias imagens das senhoras vestidas de santa; o interessante é que o referencial criativo saiu das ruas e, naquele momento de vestir as pessoas que ali estavam, voltou para esse corpo cotidiano, saiu das passarelas, do evento comercial. E quando eu vesti as pessoas que estavam ali, acabou fazendo todo o sentido do corpo, da cor da pele, do cabelo, tudo fazia sentido. As referências, as propostas, as coleções estavam sendo utilizadas por quem realmente deveria usá-las. Foi muito louco!

Como você lida com essa realidade do retorno a essa memória afetiva da sua composição?

Eu acredito que foi um privilégio! Na moda tudo fica tão superficial... A própria comunicação de moda faz tudo ser acelerado. Todos nós ficamos tentando a cada coleção acertar um lugar de referências interessantes e que traduzam nosso processo. 0 "Moda para Todos" na abertura do Colóquio foi uma oportunidade incrivel. 0 que aconteceu ali foi especial e é pro resto da vida! Mudou o meu pensamento sobre criação em moda.

Todos os depoimentos das pessoas que se inscreveram para desfilar falam de autoestima. De que forma estamos precisando transformar nossa vulnerabilidade em uma potência no mundo? Como o processo de criação que une a roupa com o corpo em um determinado ambiente pode fazer com que as pessoas se reconheçam? 0 que acontecia com você, João, quando vestia cada pessoa e sentia que era aquilo... que estava ajustado, que aconteceu, que a pessoa certa estava usando a roupa certa?

Eu sentia que tinha rolado, que vestiu incrivel. Nem precisava olhar diretamente para a pessoa. Eu sentia, eu sabia pelo que sentia de resposta do corpo vestido da pessoa, não pela feição, mas pela postura que ela assumia quando vestida. Era tudo muito rápido, havia muitas pessoas pra vestir, eu estava ali vestindo a pessoa, amarrando o sapato e sabia que tinha rolado, pela energia da pessoa. Você acha que eu estou viajando? É o perceber de como o corpo relaxa, como o corpo preenche o espaço dentro da historia que a roupa traz. Tá de um jeito e, de repente, você não precisa olhar. Você percebe que o corpo se satisfaz, que encontra morada. 
Quando você fala sobre o que você sente em vestir alguém, eu entendo o que você está descrevendo, eu já senti este encontro vestindo sua criação, João. É bom demais. 0 difícil é tirar a roupa e voltar pra casa com meu corpo "normal" de volta ao cotidiano.

Então, não tem essa de perguntar aos que vestiam as roupas se estavam felizes ou tristes. Se estava bom ou ruim. Lá na estação ferroviária não tínhamos tempo e então foi o exercício direto de observar esse tipo de sensação ao vestir as pessoas. Vestia uma e aí já vinha outra pessoa. Eu tenho interesse no olho no olho. Eu sou uma pessoa assim e, acredite, eu ali estava mais tímido do que as pessoas que se inscreveram para desfilar. Eu também estava ali numa condição de servir, de ser aceito pelas pessoas e não tinha o tempo de ficar olhando nos olhos etc. e tal. Uma situação nova, inusitada e que eu nunca havia vivido. Era uma relação de corpos (o meu e o das pessoas) e as roupas. Não tinha a mente, assim, refletindo o que fazer, sabe? Tinha que fazer, executar e fazer funcionar em curto espaço de tempo. Não tinha o tempo para a fala: você gosta disso? Você tá se sentindo bem com isso? Como está vestido? Sente-se confortável? Tinha que funcionar com outros sentidos funcionando ali. Estava em conexão total, superconectado, e eu sabia ou percebia que a pessoa vestiu bem, que estava bem pela energia dela. Lembrei de um depoimento da Rei Kawakubo [designer japonesa, fundadora da marca Comme des Garçons], sobre o processo de criação dela ser sem referencial. Ela diz que prefere sentir o que deve fazer e não ficar criando assuntos pra descobrir o que precisa ser feito.

Pensando sobre essa realidade, é incrivel quando esse corpo é o lugar onde a arte de vestir e ser vestido acontece e oferece abertura a possiveis fabulações nesses encontros.

Tinha uma outra coisa acontecendo ali que eu achei interessantíssima: quando você faz uma roupa deslumbrante e coloca essa peça em uma modelo incrivel, tudo fica absurdo! Mas o que me chamou muito atenção, para além desse corpo da moda, é que ali estávamos trabalhando com pessoas de diversas idades e cada uma com seu corpo e medidas. Para mim foi incrivel descartar todo e qualquer pensamento que evocasse a futilidade da busca desse corpo "perfeito" ao qual estou acostumado na moda. E ver que esse complemento "minha roupa + corpo do outro" resulta no corpo perfeito, então nem preciso trabalhar tanto assim, entende? É como se a roupa que crio pudesse e tivesse que encontrar seu par.

0 interessante desse trabalho é que o que tínhamos ali como proposta era desconhecido entre as partes e que o objetivo de quem organizava era o de que ficasse incrivel. Ponto. Não tinha fuga... não tinha a artimanha do 
corpo perfeito de passarela pra dar a assinatura em baixo. Não tinha ensaio e não tinha tempo para o processo. Tudo aconteceria no mesmo dia, na sequência de momentos... imagina!

Geralmente, o que eu percebo no dia a dia, no processo criativo e no fazer moda, e ao pensar a imagem de moda, o que acontece é você vestir um "corpinho" incrivel... (geralmente as modelos que possuem medidas padrão). Aí você pede para a modelo colocar a mão ali, aqui, a mão no bolso pra ajustar um caimento, e está pronto, tá feita a imagem. Aliás, é o que mais tem, né? É o que nós vemos nas imagens de moda: a gente coloca a mão aqui, puxa ali, ajusta a camisa, a calça e pronto! Tudo devidamente organizado. Eu acho que a maior parte de composição de imagens de moda é "ajeito".

\section{"Ajeito"? Essa palavra é interessante, né? "Ajeito" pra quê?}

Vai "ajeitando" pra ficar e arrumar até se ajeitar da melhor forma possivel. E nós sempre estamos nos ajeitando a alguma forma de mensagem preestabelecida. Tentando se moldar. É isso.

E quando a provocação surge desse corpo "real"? Compõe novas formas de pensar e de fazer o trabalho?

Nosso trabalho quase sempre é para os outros, né? Não é pra gente. Será que nós fazemos somente pensando na aprovação do outro? Talvez no dia a dia sim, mas tem momentos especiais nos quais ocorre a magia da empatia.

Quando você aceitou esse convite da Mônica Moura e do Colóquio de Moda, aceitou o imaterial, o não dado e pronto. Aceitar a vida como ela é. Fugia da rotina do seu fazer criativo?

Eu acho que essas provocações da vida é que promovem novas oportunidades, um novo ponto de vista. Que energia, né? Um novo estado de escuta. Cada um somou muito durante este encontro.

A última vez em que estivemos aqui, nós vimos a sua loja, que mais parece uma galeria de arte, e você é assim "acidental"! Você utiliza esse movimento do dia a dia como processo de criação de ambiente e de moda como modo de existir. É extremamente potente seu trabalho. Porque quando chegamos aqui e entramos em contato, no seu campo de ação, sentimos no corpo essa avalanche de informações reverberar. Sua arte propõe diversos níveis de cores e expansões, dialoga com quem se aproxima. Agradecemos a você, João! 


\section{O que significou participar do desfile para os inscritos?}

Figura 8: Juliana Videla e reprodução do seu depoimento escrito após a participação no desfile "Moda para Todos"

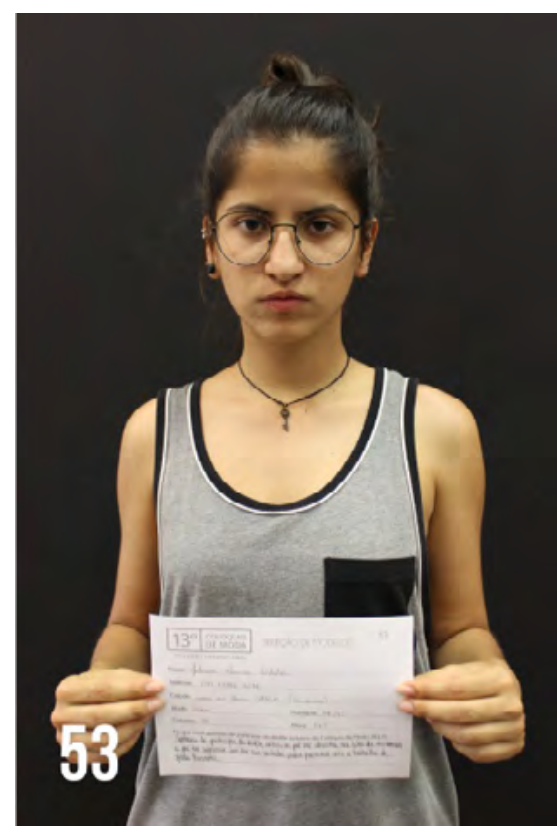

Fonte: fotografia de Rogério Ortiz (2017).

"Quando descobri que estavam fazendo testes que selecionariam pessoas para participar do desfile, percebi em mim uma vontade, ainda que tímida, de fazer parte dessa ocasião. Principalmente, sabendo que uma das diretrizes dessa escolha era o plural. A inclusão de pessoas, independente de seu respectivo gênero, idade, peso, estilo. Enxerguei a oportunidade de praticar uma militância pessoal, que envolve a desconstrução de padrões e, além disso, a busca pela igualdade de gênero.

No momento em que fui informada que poderia participar do evento dessa maneira, me senti feliz. Feliz, pois seria uma experiência nova, e me vi ansiosa para os aprendizados que viriam a surgir.

Para tornaro desfile viável, foram necessários alguns ensaios no local do mesmo, a Estação Ferroviária de Bauru, que se encontra, atualmente, desligada de suas funções iniciais (transporte de pessoas e cargas). Tive, então, não só o prazer de conhecer esse local importante para a história da cidade, como também contribuir com o evento, através da participação do desfile.

Após o ensaio e a prova de roupas (onde pude notar a seriedade e, ao mesmo tempo, a naturalidade com que a equipe trabalhava). E então, quando o momento do desfile chegou, senti uma combinação de responsabilidade e inibição, por estar fazendo parte de algo importante e estar sendo vista por muitas pessoas; e, também, uma sensação de 'dever cumprido.'

Por último, mas não menos importante, poder estar em contato com as fotos finalizadas trouxe à tona um sentimento de gratidão por ter tido a chance de participar do evento de múltiplas formas, por ter me conectado a pessoas tão diferentes de mim, por ter vivido a sinergia que foi o desfile e sua preparação". 
Figura 9: Gustavo S. e reprodução do seu depoimento escrito após a participação no desfile "Moda para Todos"

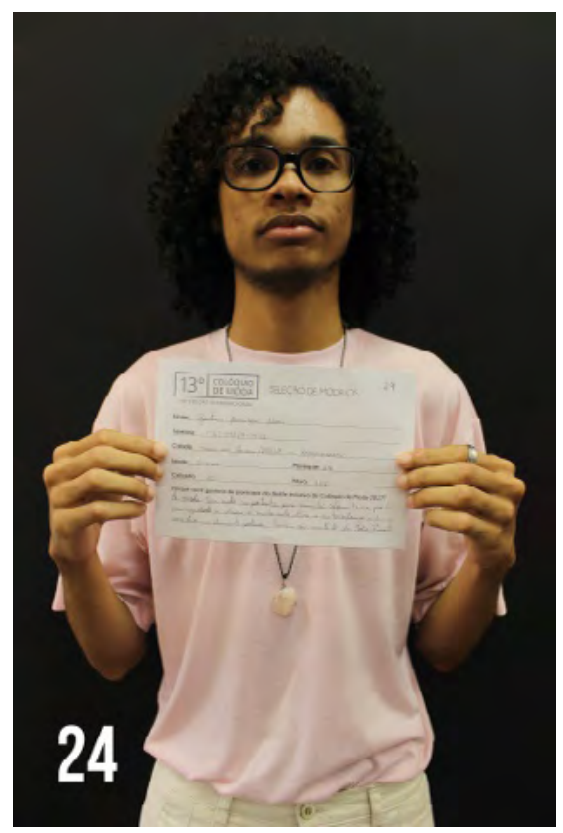

Fonte: fotografia de Rogério Ortiz (2017).

"A moda tem sido fundamental em minha vida já há alguns anos, crucial, inclusive, no meu processo de cultivo da própria auto-estima. É nítida, para mim, a diferença entre como eu me percebo agora e como eu me percebia há uns anos atrás - e como a vestimenta influenciou essa mudança (hoje, independentemente do que eu vista, eu me amo, mas a situação já foi bem diferente). É isso o que me motiva e me cativa na moda, e foi o que me fez participar do Colóquio de Moda, de um modo geral - e, também, a comunicação que a moda pretende e o meio de expressão que ela é.

Quando fiquei sabendo do desfile do João Pimenta, quase caí para trás. É um estilista que eu admiro muito e não pensei duas vezes antes de me inscrever para essa experiência (ainda bem, porque foi uma oportunidade muito engrandecedora). Eu nunca havia desfilado antes, muito menos participado de um ensaio fotográfico com um profissional, então foi tudo muito novo para mim.

Assim como a moda tem feito, de um modo geral (e muito mais pessoal), essa experiência toda me ajudou a compreender, de um modo mais amplo, toda a potencialidade do meu corpo e todas as suas possiblidades, tudo em um ambiente confortável, e de forma muito amigável. Todas as pessoas envolvidas fizeram questão de criar uma atmosfera e um ambiente muito propício a novas experiências, que eu espero jamais esquecer.

A Estação Ferroviária de Bauru (com a qual nunca tive qualquer ligação afetiva, já que não sou da cidade), linda como é, me deixou boquiaberto, desde a primeira vez que a vi. Hoje, no entanto, ela tem um significado muito maior, muito mais meu, e eu só posso agradecer por esse momento tão especial e catalizador!" 
Figura 10: Rebeca Oliveira Cavenaghi e reprodução do seu depoimento escrito após a participação no desfile "Moda para Todos"

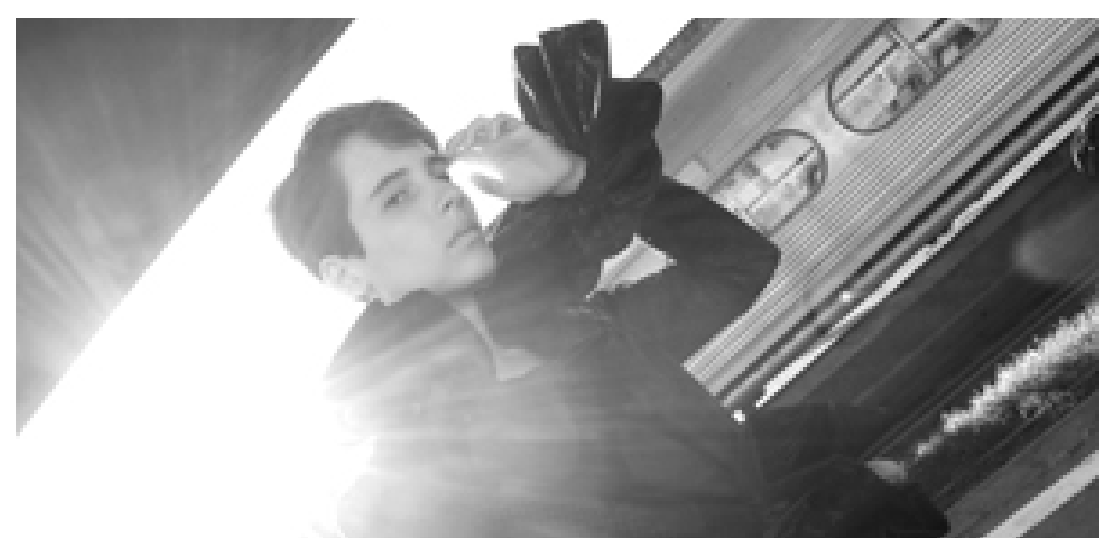

Fonte: fotografia de Rogério Ortiz (2017).

"Quando falamos de moda, falamos de padrões. Padrões de beleza, padrões físicos, padrões de gênero. Um conjunto de inúmeras regras que nos dizem como devemos pensar, ser e agir. A moda, estampada em capas de revistas fashion e reproduzida na televisão por socialites famosos, representa uma realidade utópica e inalcançável, distante da maioria, reservada àqueles poucos que têm a sorte de se encaixar nos moldes pressupostos.

0 desfile de João Pimenta, na abertura do $13^{\circ}$ Colóquio de Moda, rompeu com todas essas exclusividades. Subitamente, nos foi oferecido que desfilássemos para um estilista profissional e condecorado, e expuséssemos nossa verdadeira imagem para o público através de uma moda que, pela primeira vez, nos complementava.

Manequins, antes anônimos, contaram histórias de vida nunca antes ouvidas. Nossas diferenças (e haviam muitas) conversavam entre si, em um festival de diversidade, compondo uma obra instável, que se transformava a cada instante, genuína e verdadeiramente nossa.

Trabalhamos ao lado de uma equipe única, que se dispôs a trazer a originalidade de dentro de cada participante do desfile. Naquele momento, a moda inclusiva de João Pimenta, assim como o trabalho de todos os profissionais envolvidos, celebravam tudo aquilo que jamais foi divulgado, seja vestindo modelos em passarelas elitizadas ou em propagandas midiáticas veiculadas em meios de informação.

A moda inclusiva, assim, se transforma em ferramenta de modificação social, uma denúncia das opressões sofridas pelas minorias em um cotidiano desamparado. Por alguns minutos, nossas histórias receberam os holofotes da atenção do público, e puderam ser lidas através das roupas que vestiam nossos corpos. Alguns momentos foram gravados para sempre em fotografias, e servirão para que os nossos gritos de resistência cheguem ainda mais longe.

Sou muito grato pela oportunidade que tive de poder me apresentar e representar aqueles que são como eu. Em uma realidade que cede pouco espaço à diversidade, toda ação remediadora é nobre. Que experiências como as que tivemos possam ser cada vez mais comuns."

${ }^{1}$ Todos os depoimentos apresentados junto às fotografias foram extraidos dos textos escritos pelos próprios candidatos no formulário de inscrição para participação do desfile "Moda para Todos", que ocorreu em setembro de 2017, em Bauru, como parte da programação do 13 Colóquio de Moda. 